\title{
Vertical reflector for bifacial PV-panels
}

Jakobsen, Michael Linde; Thorsteinsson, Sune; Poulsen, Peter Behrensdorff; Rødder, Peter Melchior; Rødder, Kristin

Published in:

IEEE 43rd Photovoltaic Specialist Conference 2016

Link to article, DOI:

10.1109/PVSC.2016.7750136

Publication date:

2016

Document Version

Peer reviewed version

Link back to DTU Orbit

Citation (APA):

Jakobsen, M. L., Thorsteinsson, S., Poulsen, P. B., Rødder, P. M., \& Rødder, K. (2016). Vertical reflector for bifacial PV-panels. In IEEE 43rd Photovoltaic Specialist Conference 2016 (pp. 2678-2681). IEEE.

https://doi.org/10.1109/PVSC.2016.7750136

\section{General rights}

Copyright and moral rights for the publications made accessible in the public portal are retained by the authors and/or other copyright owners and it is a condition of accessing publications that users recognise and abide by the legal requirements associated with these rights.

- Users may download and print one copy of any publication from the public portal for the purpose of private study or research.

- You may not further distribute the material or use it for any profit-making activity or commercial gain

- You may freely distribute the URL identifying the publication in the public portal

If you believe that this document breaches copyright please contact us providing details, and we will remove access to the work immediately and investigate your claim. 


\title{
Vertical reflector for bifacial PV-panels
}

\author{
Michael Linde Jakobsen ${ }^{\mathrm{a}}$, Sune Thorsteinsson, ${ }^{*, a}$, Peter Behrensdorff Poulsen ${ }^{\mathrm{a}}$, Peter Melchior Rødder ${ }^{\mathrm{b}}$ and \\ Kristin Rødder ${ }^{\mathrm{b}}$
a Department of Photonics Engineering, Technical University of Denmark, Frederiksborgvej 399, Building 130, 4000 Roskilde, Denmark, *mlja@fotonik.dtu.dk, phone: +45 46774556
${ }^{\mathrm{b}}$ SolarLab, Gunnar Clausens Vej 9, DK-8260 Viby J., Denmark

\begin{abstract}
Bifacial solar modules offer an interesting price/performance ratio, and much work has been focused on directing the ground albedo to the back of the solar cells. In this work we design and develop a reflector for a vertical bifacial panel, with the objective to optimize the energy harvest for the winter. Raytracing modelling is used to simulate the reflector, and initial simplified simulations indicates a significant gain in energy harvest that increase with increasing latitude for the winter. The simulations also show energy gain for the summer, however, not as significant as for the winter and the summer gain is almost independent of latitude.
\end{abstract}

\section{INTRODUCTION}

Bifacial solar modules has in the recent years become an attractive commercially available newcomer to the solar industry, due to the fact that the energy performance of a bifacial cell in the right orientation increases the energy harvest significantly, while only providing an additional module cost of approximately $30 \%$ [1]. Several works have proven that adding reflectors to bifacial panels mounted at a certain optimized tilt, increases the energy harvest even further [2]-[4], and bifacial panels has offered new solutions as e.g. PV based fences [5]. For PV-systems mounted at a tilt, the reflectors will in many cases be placed underneath the PV panel to reflect incident light from surroundings e.g. the albedo. Since these reflectors are not exposed to rain they do not have the same self-cleaning ability as the PV panels itself and the resulting energy harvest is decreased due to soiling [2], [4]. It has also been modeled that the use of bifacial PV panels in solar farms can reduce the needed storage for the power system, since the peak power times can be shifted closer to the power demand [6].

In this work we propose a system using a vertical mounted bifacial panel using vertical reflectors at angle to both reduce the soiling problem, but also to optimize the energy harvest during winter, where there is shortage of solar energy. The reflector is optimized using raytracing modelling of the optical rays, where the details of the reflections at the optical interfaces are taken into consideration.

\section{REFLECTOR DESIGN AND RAY-TRACING}

For this initial design a bifacial panel being one cell wide is used. A preliminary system design is shown in Fig. 1, which is comprised of a vertical bifacial panel which for simulation is oriented east west, and two reflector plates extending in angles $(\alpha)$ of \pm 45 deg. relative to the bifacial panel. The working principle is shown in Fig. 1. The design offers a tubular embodiment with a "hat" on top, which in combination with the vertical surfaces reduces the soiling of the system significantly. In a further development where the reflectors could be concentrating the sun, the tubular design can be optimized for efficient natural convection.

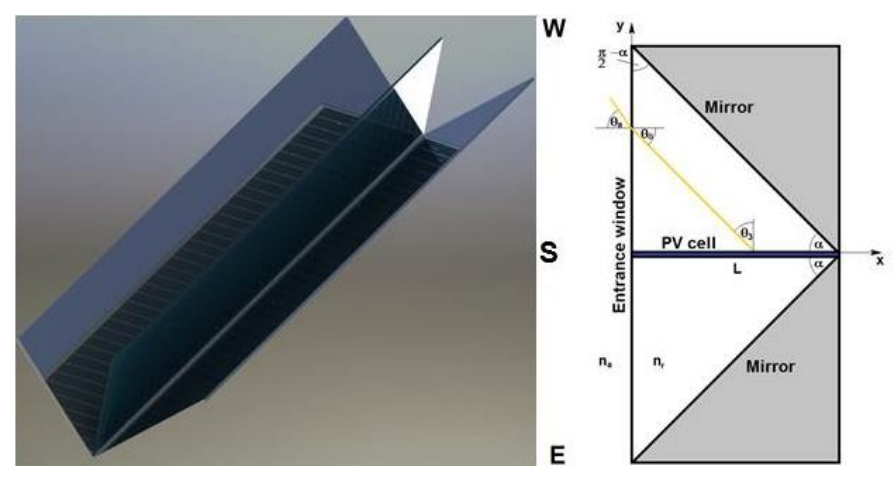

Fig. 1. Illustration of the reflector system.

The optical paths of the light incident on the retro-reflector are modelled with our Ray tracing model with the objective of winter optimization.

The volume inside the retroreflector is filled with a medium with a refractive index $n_{r}$, which optionally can be different from the refractive index $\left(n_{a}\right)$ of air. If $n_{r}=n_{a}$ the model ignores the medium. In case $n_{r} \neq n_{a}$ the medium is present in the model and it will encapsulate the retroreflector with a flat window (the entrance window to the retroreflector) opposing the top angle of the reflector, see Fig. 1.

The optical paths of the light incident on the retro-reflector are modelled with our ray tracing model.

The PV-module is a glass-glass module, with EVA as encapsulant. In case we select $n_{r}=1.5$ (the refractive index of glass) for the medium inside the retroreflector the interface to this laminate vanish and in that case we assume that the PV cells absorb all the incoming light - independent of its angular incidence. This allows us to consider only three paths of the incoming light, and these are illustrated in Fig. 2. 
1. Refraction at the entrance window and then propagation to the PV-cell.

2. Refraction at the entrance window, then propagation to the mirror, where reflection occurs and then propagation to the PV-cell.

3. Refraction at the entrance window, then propagation to the mirror, where reflection occurs, then propagation to the entrance window, where refraction and reflection occurs and the reflected part propagates to the PV-cell.

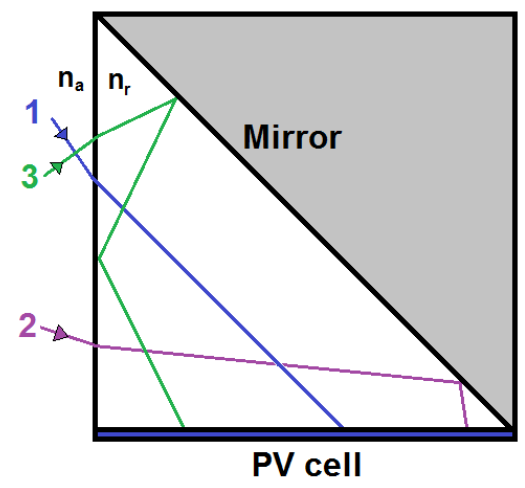

Fig. 2. Relevant paths in one half of the retroreflector, when assuming that the PV cell absorbs all light.

In case we select $n_{r}=1.0$ for the medium inside the retroreflector the interface to the PV laminate will be dealt with as a dielectric interface, and the Fresnel equations are used. When the ray intersects with a mirror interface we use a reflection coefficient of $95 \%$, as an average value for the reflection coefficient of alumina throughout the spectral range of $\mathrm{c}-\mathrm{Si}$. The solar elevation $(\psi)$ is determined from the local latitude $(\varphi)$, the declination of the sun $(\delta)$ and the azimuth angle $(\theta)$ of the sun relative to the local true south:

$$
\psi=\sin ^{-1}[\sin \varphi \sin \delta+\cos \varphi \cos \delta \cos \theta]
$$

The schematic illustrates the model of the vertical retroreflector, and its orientation relative to earth. At the moment, the model does not include the diffuse solar contribution as well as optical absorption in the medium inside the retroreflector. This preliminary model does not include variations in sun intensity but considers only the projection of the AM 1.5 spectrum and resulting scattering due to the Fresnel equations.

\section{RESULTS}

As a reference to our simulations on the retroreflector, the light incident on vertical mono-facial panel facing south is simulated, calculating the sun path for the specific latitude. The integral of the irradiance curve is then used as reference. An example of a reference curve is shown in Fig. 3.

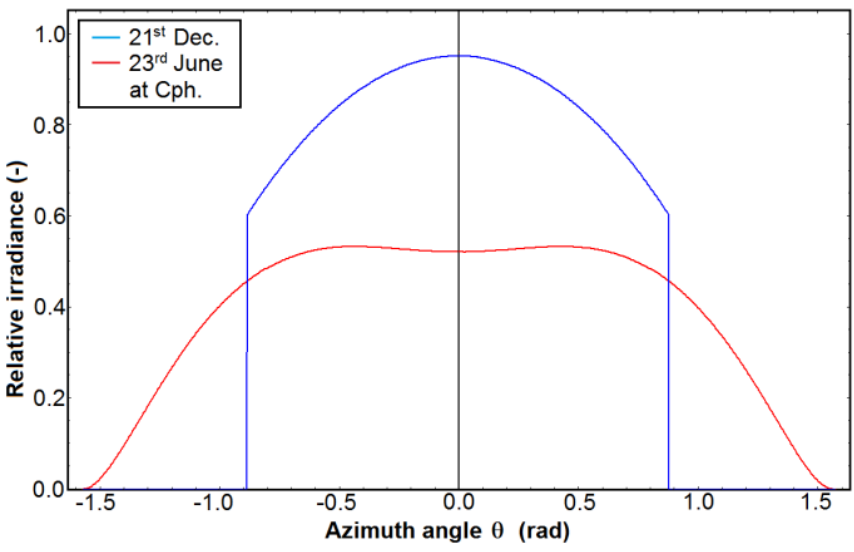

Fig. 3. The simulated relative irradiance for the reference case located in Copenhagen.

The small decrease at noon for the summer is owing to the sun height, and the vertical mounted panel, and the sharp winter cutoff is due to the fact that only the projection of the direct sunlight is considered. Four cities placed at different latitudes are very similar longitudes are chosen to for the simulations: Trondheim (Norway latitude $63.5^{\circ} \mathrm{N}$ ), Copenhagen (Denmark lat. $55.7^{\circ} \mathrm{N}$ ), Munich (Germany lat. $48.1^{\circ} \mathrm{N}$ ) and Rome (Italy lat. $\left.41.9^{\circ} \mathrm{N}\right)$. The shortest and the longest days of the year are simulated and the relative irradiances as a function of azimuthal angle are used to normalize for the energy harvest.

The retroreflector is simulated with the reflector volume containing air $\left(n_{r}=1\right)$, and the glass laminate on the PV-cell reflects light according to Fresnel's equations.

A plot of the relative irradiance from East to South, is shown in Fig. 3 for the longest day of the year. In these simulations the irradiation is symmetrically around $0^{\circ}$, since clear sky days are modelled, and the modules bifaciality is ignored (bifaciality is the ratio of the modules front side and back side efficiency, which in most cases differs slightly). The plot in Fig. 4 illustrates the different contributions from the optical paths present in the retroreflector.

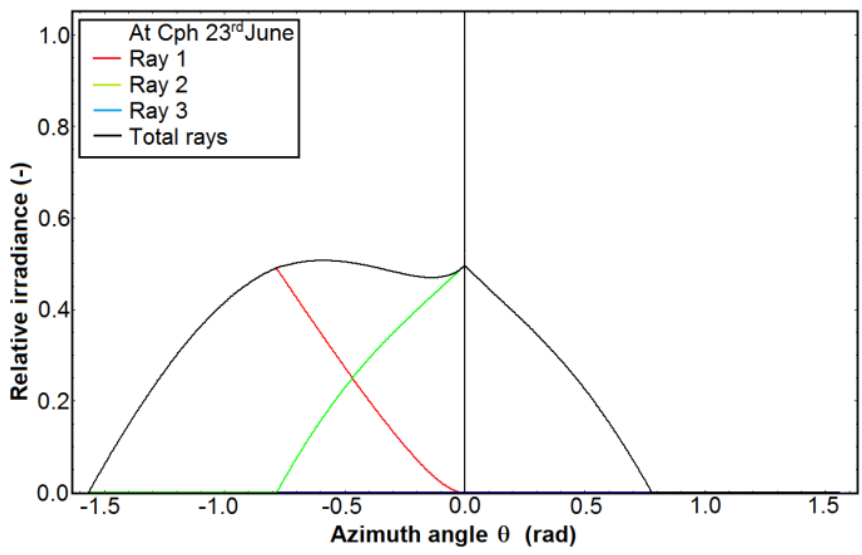

Fig. 4. The simulated relative irradiance for the upper half of the bifacial PV-cell with the retroreflector 
The red curve is the light incidence directly onto the PV-cells (1). The green curve illustrates light, being reflected in the retroreflector before it hits the PV-cells (2). The third option is not present for $n_{r}=n_{a}$. The total irradiance for the entire retroreflector is plotted in Fig. 5.

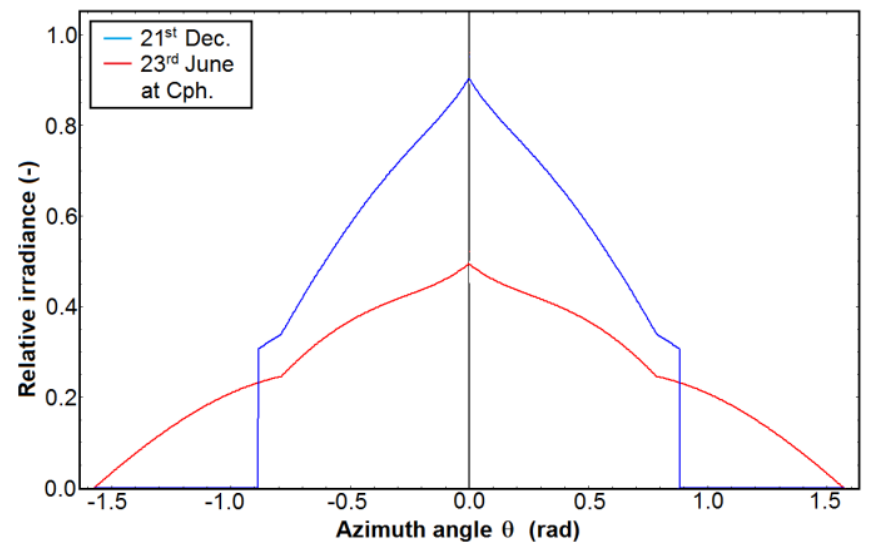

Fig.5. The simulated relative irradiance for the upper half of the bifacial PV-cell with a retroreflector filled with a medium with a refractive index of 1.5 .

Table 1 shows the energy gain for the longest and the shortest day at the chosen locations compared to the monofacial south oriented reference. Since all simulations are normalized the same area, being the area of the reference setup at normal incidence, the non-concentrating retro reflector can give a maximum energy gain of 2 . Our intensions are to design a reflector that can deliver an energy output at a value as close to two as possible.

TABLE I.

IMPROVEMENT COMPARED TO MONO-FACIAL REFERENCE.

\begin{tabular}{|l|l|l|l|}
\hline Place & Latitude & $\begin{array}{l}\text { Improvement } \\
\text { December }\end{array}$ & $\begin{array}{l}\text { Improvement } \\
\text { June }\end{array}$ \\
\hline Trondheim & 63.5 & 1.68 & 1.36 \\
\hline Copenhagen & 55.7 & 1.45 & 1.35 \\
\hline Munich & 48.1 & 1.39 & 1.33 \\
\hline Rome & 41.9 & 1.38 & 1.35 \\
\hline
\end{tabular}

\section{DISCUSSION}

Initial simulations, have shown that the retroreflector increases the energy output on a winter day by $30-70 \%$ relative to our reference setup, and a constant gain of approximately $35 \%$ for the summer, almost independent of latitude. The improvement could be extended further by inserting an index matched medium discussed above, inside the retroreflector, however due to the long optical path optical absorption needs to be considered.

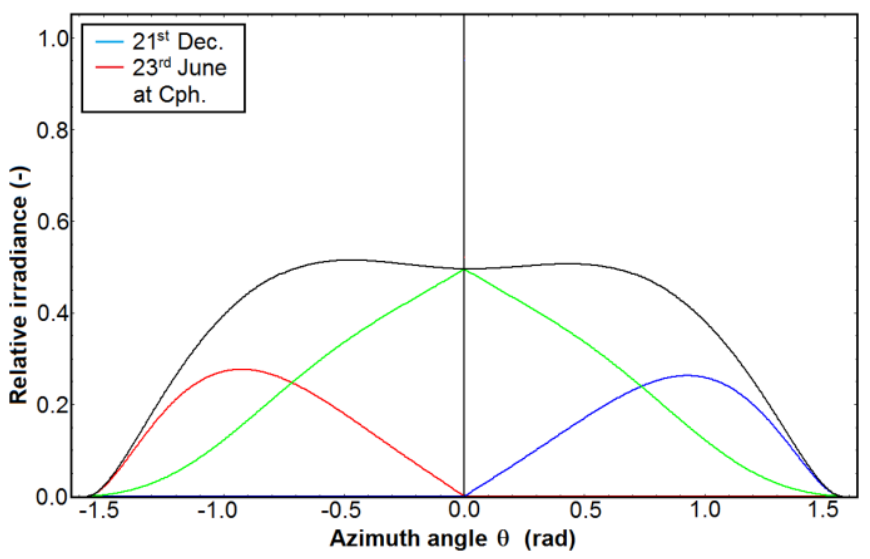

Fig 6. The simulated relative irradiance for the upper half of the bifacial PV-cell with a retroreflector filled with a medium with a refractive index of 1.5 .

Fig 6 illustrates that the third optical path appears as a significant contribution to the total irradiance for the longest day, and relative contribution depends on the latitude. In the four cases listed in Table 1 the gain is highest at the highest latitude, however this figure might change once diffuse meteorological irradiation data is used.

\section{SUMMARY AND FUTURE WORK}

An optical model for the retroreflector has been created based on raytracing. Initial simulations, have shown that the retro reflector increases the energy output on a winter day by $30-70 \%$ relative to the reference setup and is strongly increasing with latitude. The next steps are to field test a reflector model at our Copenhagen based laboratory and advance the model with diffuse contribution and meteorological irradiation data.

\section{REFERENCES}

[1] G. João, "Testing bifacial PV cells in symmetric and asymmetric concentrating CPC collectors," Engineering, vol. 05, no. 01, pp. 185-190, 2013.

[2] A. Moehlecke, F. S. Febras, and I. Zanesco, "Electrical performance analysis of PV modules with bifacial silicon solar cells and white diffuse reflector," Sol. Energy, vol. 96, pp. 253262, 2013.

[3] G. E. Ahmad and H. M. S. Hussein, "Comparative study of PV modules with and without a tilted plane reflector," Energy Convers. Manag., vol. 42, no. 11, pp. 1327-1333, 2001.

[4] A. Luque, E. Lorenzo, G. Sala, and S. López-Romero, "Diffusing reflectors for bifacial photovoltaic panels," Sol. Cells, vol. 13, no. 3, pp. 277-292, 1985.

[5] R. J. Magasrevy, "Bifacial efficiency at monofacial cost Building Integrated photovoltaic Energy Solutions for the World," p. 25, 2007.

[6] S. Obara, D. Konno, Y. Utsugi, and J. Morel, "Analysis of output power and capacity reduction in electrical storage facilities by peak shift control of PV system with bifacial modules," Appl. Energy, vol. 128, pp. 35-48, 2014. 